V. A. Tumanskiy, T. A. Khrystenko

\title{
Comparative immunohistochemical characteristic of expression levels of Ki-67, p53, caspase 3 in non-invasive and invasive intestinal-type gastric adenocarcinoma
}

Zaporizhzhia State Medical University

Key words: Stomach Neoplasms, Adenocarcinoma, Cell Proliferation, Tumor Suppressor Protein p53, Caspase 3.

Aim. Comparison analysis of expression levels of Ki-67, p53, and caspase 3 was performed between the tumor cells and the stromal cells of non-invasive intestinal-type gastric adenocarcinoma on the one hand and the tumor cells and the stromal cells of invasive intestinal-type gastric adenocarcinoma on the other hand.

Materials and methods. For this purpose, pathohistological and immunohistochemical studies were used. The surgical material of 10 patients with non-invasive (pTis, pT1) intestinal-type gastric adenocarcinoma and 10 patients with invasive (pT2, pT3, pT4) intestinaltype gastric adenocarcinoma were analyzed.

Results. It was established that intestinal-type gastric adenocarcinoma is characterized by the medium Ki-67 labeling index, the low expression level of p53, the low expression level of caspase 3 in the tumor cells, and also the low Ki-67 labeling index and the extremely low expression level of caspase 3 in the stromal cells. The tumor cells of invasive intestinal-type gastric adenocarcinoma are characterized by the 2 times higher expression level of $\mathrm{p} 53$, than the tumor cells of non-invasive intestinal-type gastric adenocarcinoma. Moreover, direct correlation between the medium Ki-67 labeling index of the tumor cells and the low Ki-67 labeling index of the stromal cells, and also direct correlation between the medium Ki-67 labeling index in the tumor cells of intestinal-type gastric adenocarcinoma and the low expression level of p53 in these cells were identified.

Conclusions. These data demonstrate a significantly more activity of proliferation and apoptosis in the tumor cells of intestinal-type gastric adenocarcinoma, in comparison with the stromal cells of this tumor. Invasive intestinal-type gastric adenocarcinoma differs by the 2 times higher expression level of p53, in comparison with the same index for non-invasive carcinoma. Furthermore, a tight association between proliferative processes in the tumor cells and in the stromal cells of intestinal-type gastric adenocarcinoma, and also an association between proliferative processes and accumulation of mutant protein p53 in the tumor cells of intestinal-type gastric adenocarcinoma were identified.

Порівняльна імуногістохімічна характеристика експресії Ki-67, p53, каспази-3 в неінвазивній та інвазивній аденокарциномі шлунка кишкового типу

В. О. Туманський, Т. О. Христенко

Мета роботи - порівняти рівні експресії маркерів Ki-67, p53, каспази-3 в пухлинних клітинах і клітинах строми неінвазивної та інвазивної аденокарциноми шлунка кишкового типу, а також дослідити наявність кореляційних зв'язків між рівнями експресії відзначених маркерів.

Матеріали та методи. Здійснили патогістологічне та імуногістохімічне дослідження операційного матеріалу 10 хворих на неінвазивну (pTis, pT1) аденокарциному шлунка кишкового типу, а також 10 хворих на інвазивну (pT2, pT3, pT4) аденокарциному шлунка кишкового типу.

Результати. Встановлено, що аденокарцинома шлунка кишкового типу характеризується середнім індексом проліферації, низьким рівнем експресії р53, низьким рівнем експресії каспази-3 в пухлинних клітинах, а також низьким індексом проліферації та вкрай низьким рівнем експресії каспази-3 у клітинах строми. При цьому для пухлинних клітин інвазивної аденокарциноми шлунка кишкового типу є характерним удвічі більший рівень експресії р53, аніж для пухлинних клітин неінвазивної аденокарциноми шлунка кишкового типу. Крім того, виявлено наявність прямого кореляційного зв'язку між середніми значеннями індексу проліферації пухлинних клітин і низькими значеннями індексу проліферації клітин строми аденокарциноми шлунка кишкового типу, а також наявність прямого кореляційного зв'язку між середніми значеннями індексу проліферації пухлинних клітин аденокарциноми шлунка кишкового типу та низьким рівнем експресії р53 у них.

Висновки. Дані свідчать про значно більшу активність проліферативних та апоптотичних процесів у ракових клітинах аденокарциноми шлунка кишкового типу порівняно з клітинами строми цієї пухлини. Інвазивну аденокарциному шлунка кишкового типу відрізняє вдвічі більший показник рівня експресії р53 порівняно з аналогічним показником неінвазивної карциноми. Окрім того, отримали дані, що свідчать про асоціацію проліферативних процесів у пухлинних клітинах і клітинах строми аденокарциноми шлунка кишкового типу, а також про асоціацію проліферативних процесів і накопичення мутантного білка р53 в пухлинних клітинах аденокарциноми шлунка кишкового типу.

Ключові слова: новоутворення шлунка, аденокариинома, проліферація, онкосупресорний протеїн р53, каспаза-3.

Патологія. - 2016. - № 2 (37). - C. 70-75

Сравнительная иммуногистохимическая характеристика экспрессии Кi-67, p53, каспазы-3

в неинвазивной и инвазивной аденокарциноме желудка кишечного типа

В. А. Туманский, Т. А. Христенко

Цель работы - сравнить уровни экспрессии маркеров Ki-67, p53, каспазы-3 в опухолевых клетках и клетках стромы неинвазивной и инвазивной аденокарциномы желудка кишечного типа, а также изучить корреляционные связи между уровнями экспрессии данных маркеров. 
Материалы и методы. Проведено патогистологическое и иммуногистохимическое исследование операционного материала 10 больных неинвазивной (pTis, pT1) аденокарциномой желудка кишечного типа, а также 10 больных инвазивной (pT2, pT3, pT4) аденокарциномой желудка кишечного типа.

Результаты. Установлено, что аденокарцинома желудка кишечного типа характеризуется средним индексом пролиферации, низким уровнем экспрессии р53, низким уровнем экспрессии каспазы-3 в раковых клетках, а также низким индексом пролиферации и крайне низким уровнем экспрессии каспазы-3 в клетках стромы. При этом для опухолевых клеток инвазивной аденокарциномы желудка кишечного типа характерен в 2 раза более высокий уровень экспрессии р53, чем для опухолевых клеток неинвазивной аденокарциномы желудка кишечного типа. Кроме того, выявлена прямая корреляционная связь между средними значениями индекса пролиферации опухолевых клеток и низкими значениями индекса пролиферации клеток стромы аденокарциномы желудка кишечного типа, а также прямая корреляционная связь между средними значениями индекса пролиферации опухолевых клеток аденокарциномы желудка кишечного типа и низким уровнем экспрессии р53 в них.

Выводы. Полученные данные свидетельствуют о значимо большей активности пролиферативных и апоптотических процессов в опухолевых клетках аденокарциномы желудка кишечного типа в сравнении с клетками стромы данной опухоли. Инвазивную аденокарциному желудка кишечного типа отличает в 2 раза больший показатель уровня экспрессии р53 в сравнении с аналогичным показателем неинвазивной карциномы. Кроме того, получены данные, свидетельствующие об ассоциации пролиферативных процессов в раковых клетках и клетках стромы аденокарциномы желудка кишечного типа, а также об ассоциации пролиферативных процессов и накопления мутантного белка р53 в опухолевых клетках аденокарциномы желудка кишечного типа.

Ключевые слова: новообразования желудка, аденокариинома, пролиферачия, онкосупрессорный протеин р53, каспаза-3.

Патология. - 2016. - № 2 (37). - С. 70-75

$\mathrm{A}$ ccording to L. A. Torre et al. (2015), 951.600 new cases of gastric cancer (GC) and 723.100 deaths from this disease were registered throughout the world in 2012 [1]. GC rates are generally about twice as high in men as in women and vary widely across countries, traditionally incidence rates are the highest in Eastern Asia, Central and Eastern Europe, and South America [1]. According to the National Cancer Registry of Ukraine, 10291 new cases of GC and 7766 deaths from GC were registered in 2013 [2]; and also 8350 new cases of GC and 6414 deaths from this disease were registered in 2014 [3]. At the same time $\mathrm{GC}$ takes the $4^{\text {th }}$ place in the ranking of cancer incidence in men and the $8^{\text {th }}$ place in the ranking of cancer incidence in women. Moreover, GC takes the $2^{\text {nd }}$ place in the ranking of cancer related death in men and the $3^{\text {rd }}$ place in the ranking of cancer related death in women [2,3]. These data demonstrate the significant aggressiveness of GC and the imperfection of the methods of diagnosis and treatment of this disease used today.

It is known that the key event in the development of cancer is non-lethal damage of one or more genes, which control the processes of the DNA repair, apoptosis, cell proliferation and differentiation [4]. The increase of the proliferative activity, which is determined by increasing expression of nuclear $\mathrm{Ki}-67$, the decrease of the apoptosis level and the caspase 3 expression level, which is associated with the accumulation of the mutant p53 protein, are developing as a result of these mutations. Such changes have been identified in breast cancer [5], in hepatocellular and cholangiocellular liver carcinoma [6] and also in endometrial adenocarcinoma [7].

Literature data about the features of immunohistochemical expression of $\mathrm{Ki}-67, \mathrm{p} 53$ and caspase 3 in GC are contradictory. According to N. M. Fonores et al. [8] the indices of cell proliferation and apoptosis progressively increase with increasing the depth of the intestinal-type gastric adenocarcinoma invasion. L. Xiao et al. [9] indicated that the intestinal-type gastric adenocarcinoma is characterized by the higher expression level of caspase 3 and p53 (in comparison with the diffuse-type gastric adenocarcinoma), but the correlation between the expression levels of Ki-67, p53, caspase 3 and the depth of the tumor invasion was not identified.

Aim - to compare the expression levels of Ki-67, p53, caspase 3 in the tumor cells and the stromal cells of invasive and non-invasive intestinal-type gastric adenocarcinoma, and also to explore the correlations between the expression levels of these markers.

\section{Materials and methods}

Pathohistological and immunohistochemical study of non-invasive (pTis, pT1) intestinal-type gastric adenocarcinoma (10 patients, the age of the patients ranged from 45 to 83 years) and invasive (pT2, pT3, pT4) intestinal-type gastric adenocarcinoma (10 patients, the age of the patients ranged from 58 to 72 years) was performed.

The microstructure of the cancer was evaluated in the paraffin sections, which were stained by hematoxylin and eosin. IHC study was performed according to the standard procedures [10] using the monoclonal antibodies Mo a-Hu Ki-67 Antigen (Clone MIB-1, „DAKO”, Denmark), Mo a-Hu p53 Protein (Clone DO-7, "DAKO", Denmark), Mo a-Hu Caspase Ab-3 (Clone 3CSP03, "Thermo Scientific", USA) and visualization system DAKO EnVision+ with diaminobenzidine ("DAKO", Denmark). The results of the study were evaluated using the Axioplan 2 microscope ("Carl Zeiss", Germany), microsections were photographed by digital camera "Canon EOS 1000D" (Japan) with an increasing of $\times 200$ in 5 fields of view.

Nuclear expression of Ki-67 and p53 by the tumor cells and the stromal cells were studied in the digital images using Photoshop CC (2014). Proliferation index (PI) of the tumor cells and the stromal cells of the intestinal-type gastric adenocarcinoma (as percentage of cells with nuclear Ki-67 expression in the standardized field of view of a microscope [12]) was determined and, based on the data of M. Uhlén (2015), was graduated as a low (if less than $25 \%$ of immunopositive cells was determined), as a middle (if the presence of 25-75\% immunopositive cells was determined) and as a 
high (if the field of view of more than $75 \%$ immunopositive cells was determined) [14]. Expression level of p53 was determined and graduated in the same way [14].

The expression of caspase 3 by the tumor cells and the stromal cells of the intestinal-type gastric adenocarcinoma was determined by the digital morphometry method [15]. In this way, the expression level of caspase 3 was expressed in the conventional units of the optical density (CUOD) and was graduated on 4 levels: lack of expression -0-20 CUOD, the low expression level of caspase 3-21-50 CUOD, the moderate - 51-100 CUOD and the high expression level of caspase 3 - more than 100 CUOD.

Statistical processing of the results was performed on a personal computer using program "Statistica ${ }^{\circledR}$ for Windows 6.0” (StatSoft Inc., License № AXXR712D833214FAN5). The median (Me), and also the lower and the upper quartiles $\left(\mathrm{Q}_{1} ; \mathrm{Q}_{3}\right)$ were calculated. Comparison was performed using Wilcoxon t-test and Mann-Whitney U-test (the difference was considered as statistically significant when $p<0.05$ ). The study of correlations between the studied parameters was performed using Spearman's rank correlation test.

\section{Results and discussion}

Immunohistochemical studies results showed that nuclear expression of Ki-67 was determined in the tumor cells and the stromal cells of intestinal-type gastric adenocarcinoma, nuclear expression of $\mathrm{p} 53$ was determined in the tumor cells only and nuclear-cytoplasmic expression of caspase 3 was determined in the tumor cells and the stromal cells of this tumor.

The median of the PI of the tumor cells of non-invasive intestinal-type gastric adenocarcinoma was $44.46 \%$ (36.96; 80.28 ) and for invasive intestinal-type gastric adenocarcinoma the figure was $37.80 \%(28.64 ; 69.22)$. The difference between these figures was not statistically significant $(\mathrm{p}>0.05)$. According to H. Amrani et al. (2014), the proliferative activity of the tumor cells of gastric cancer (estimated by Ki-67) corresponds to the average level $(\mathrm{M}=46.4 \%)$ [11], that agrees with our data. The median of the PI of the stromal cells of non-invasive intestinal-type gastric adenocarcinoma was $3.68 \%$ (2.94; 8.94 ) and for invasive intestinal-type gastric adenocarcinoma the figure was $4.35 \%(3.72 ; 6.84)$. The difference between these figures was not statistically significant $(p>0.05)$. However, there was statistically significant difference between the PI of the tumor cells and the PI of the stromal cells in each of the study groups $(p<0.05)$. According to all these findings, we can make a conclusion, that the cancer cells of intestinal-type gastric adenocarcinoma are characterized by the middle proliferative activity level and the stromal cells of this tumor are characterized by the low proliferative activity level (Fig. 1).

It was found, that the tumor cells of intestinal-type gastric adenocarcinoma are characterized by the low expression level of p53: the median of p53 expression by the tumor cells of non-invasive intestinal-type gastric adenocarcinoma was $12.64 \%(11.40 ; 15.40)$ and for invasive intestinal-type gastric adenocarcinoma the figure was $24.99 \%$ $(6.56 ; 77.44)$. The difference between the expression levels of p53 in the study groups was statistically significant $(\mathrm{p}<0.05)$ (Fig. 2).

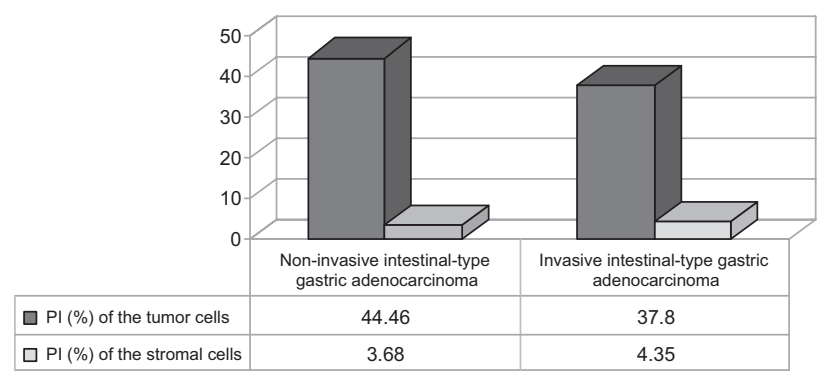

Fig. 1. The proliferation index of the tumor cells and the stromal cells of intestinal-type gastric adenocarcinoma $(p<0.05)$.

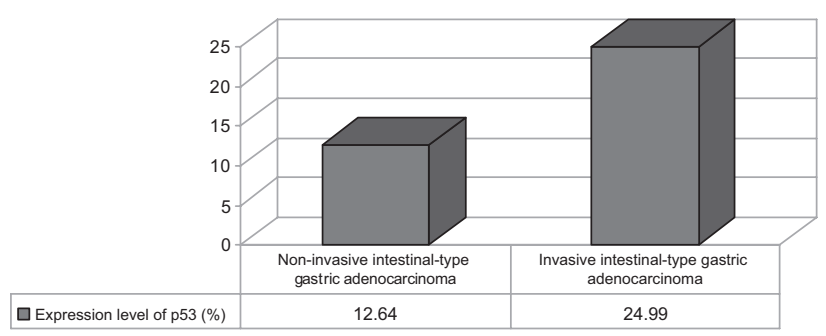

Fig. 2. The expression level of $\mathrm{p} 53$ in the tumor cells of intestinal-type gastric adenocarcinoma $(\mathrm{p}<0.05)$.

It is known, that in $60 \%$ of highly differentiated gastric cancer, including intestinal-type gastric adenocarcinoma, TP53-mutations are identified [12,14]. TP53-gene encodes the synthesis of $\mathrm{p} 53$, which is detected by the corresponding immunohistochemical reaction [13]. Literature data concerning the expression level of p53 in gastric cancer with the different parameters of the invasion depth are contradictory. H. Zheng et al. (2006) [16], and Y. Joo et al. (2006) [12] found that there is a direct correlation between the p53 expression level and the depth of invasion of gastric cancer. At the same time, L. Xiao et al. (2013) did not found any correlation between the p53 expression level and the depth of invasion of gastric cancer [9]. Our data indicate that the expression level of p53 by the tumor cells of invasive intestinal-type gastric adenocarcinoma is two times higher than the expression level of this marker by the tumor cells of non-invasive intestinal-type gastric adenocarcinoma.

It was found that the cancer cells of intestinal-type gastric adenocarcinoma are characterized by the low level of apoptosis: the median of caspase 3 expression by the tumor cells of non-invasive intestinal-type gastric adenocarcinoma was 69.35 CUOD (52.15; 95.42), and for invasive intestinal-type gastric adenocarcinoma the figure was 63.11 CUOD (45.94; 86.16). The difference between these figures was not statistically significant ( $p>0.05$ ). Moreover, our studies have shown that the stromal cells of intestinal-type gastric adenocarcinoma are characterized by the very low level of apoptosis: the median of caspase 3 expression by the stromal cells of non-invasive intestinal-type gastric adenocarcinoma was 23.54 CUOD (22.22; 25.76), and for invasive intestinal-type gastric adenocarcinoma the figure was 23.44 CUOD (22.84; 26.72). Thus, it was shown that the level of apoptosis of the 
cancer cells in intestinal-type gastric adenocarcinoma is significantly higher than the level of apoptosis of the stromal cells in this tumor $(\mathrm{p}<0.05)$ (Fig. 3).

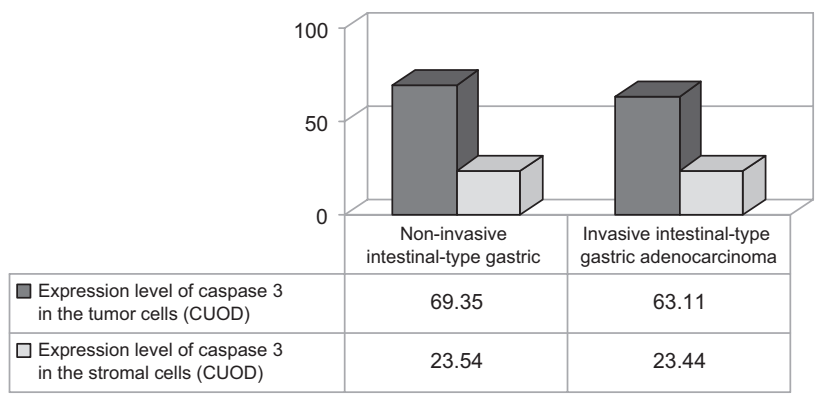

Fig. 3. The expression level of caspase 3 in the tumor cells and the stromal cells of intestinal-type gastric adenocarcinoma $(\mathrm{p}<0.05)$.

According to the literature data, the expression level of caspase 3 in normal gastric mucosa is significantly higher than in gastric cancer [9]. Our findings are agreeing with the results of L. Xiao et al. (2013), according to which, the low level or the lack of caspase 3 expression in the tumor cells in most cases of gastric cancer were revealed [9]. Our findings are also agreeing with the results of molecular-genetic studies of J. Kania et al. [17], according to which, the mRNA and protein expression of caspase 3 was detected only in normal gastric mucosa. In gastric cancer, only the expression of procaspase 3 was observed, while the expression of active caspase 3 was completely undetectable. In the gastric mucosa, surrounding gastric cancer, no gene and protein expression for caspase 3 was detected. The authors have made a conclusion that the lack of expression of the active form of caspase 3 associated with the increasing activity of survivin, whose main function is the down-regulation of apoptosis [17].

Correlation analysis showed a strong direct correlation between PI of the tumor cells and PI of the stromal cells in intestinal-type gastric adenocarcinoma: the Spearman's coefficient for the tumor cells and the stromal cells of non-invasive intestinal-type gastric adenocarcinoma was 0.87 , for invasive intestinal-type gastric adenocarcinoma the figure was 0.83 . These data indicate the close association between proliferative processes in the cancer cells and in the stromal cells of intestinal-type gastric adenocarcinoma. We could not find any original research on the issue of correlation between $\mathrm{Ki}-67, \mathrm{p} 53$, caspase 3 expression levels in the tumor cells and the stromal cells of intestinal-type gastric adenocarcinoma. As a rule, researchers tend to focus their attention on the issue of correlation between the expression levels of these markers in the cancer cells only.

A direct weak correlation between Ki-67 and p53 expression levels in the tumor cells of non-invasive intestinal-type gastric adenocarcinoma and a direct medium correlation between the same expression levels for invasive intestinal-type gastric adenocarcinoma were revealed. The Spearman's coefficient for the tumor cells of non-invasive intestinal-type gastric adenocarcinoma was 0.31 and the figure for invasive intestinal-type gastric adenocarcinoma was 0.49 . Y. Joo et al. (2006) [12] reported, that there is a direct correlation between Ki-67 and p53 expression levels in the tumor cells of gastric cancer.

Moreover, a direct strong correlation between Ki-67 and caspase 3 expression levels in the tumor cells and the stromal cells of intestinal-type gastric adenocarcinoma was determined. The Spearman's coefficient for the Ki-67 and caspase 3 expression levels in the tumor cells of non-invasive and invasive intestinal-type gastric adenocarcinoma was 0.98 . An inverse correlation between $\mathrm{Ki}-67$ and caspase 3 expression levels in the stromal cells of non-invasive intestinal-type gastric adenocarcinoma was also found: the Spearman's coefficient was -0.38. Any correlation between Ki-67 and caspase 3 expression levels in the stromal cells of invasive intestinal-type gastric adenocarcinoma was not revealed. According to our findings, increased proliferative activity in gastric cancer is associated with increased level of apoptosis. These findings are agreeing with the literature data $[8,9]$.

A direct weak correlation between p53 and caspase 3 expression levels in the tumor cells of non-invasive intestinal-type gastric adenocarcinoma, and also a direct medium correlation between the same expression levels for invasive intestinal-type gastric adenocarcinoma were revealed. The Spearman's coefficient for p53 and caspase 3 expression levels in the tumor cells of non-invasive intestinal-type gastric adenocarcinoma was 0.35 and the figure for invasive intestinal-type gastric adenocarcinoma was 0.56 . Our findings are agreeing with the literature data [9] and indicate the relationship between the accumulation of p53 in the tumor cells and the activation of apoptosis level of these cells, that measured by the nuclear-cytoplasmic expression of caspase 3 .

\section{Conclusions}

1. The tumor cells of non-invasive and invasive intestinal type gastric adenocarcinoma are characterized by the medium proliferation index, the low p53 expression level and the low caspase 3 expression level, while the stromal cells of this tumor are characterized by the low proliferation index and the extremely low caspase 3 expression level $(\mathrm{p}<0.05)$.

2. The direct correlations between the medium proliferation index and the low p53 expression level, between the medium proliferation index and the low caspase 3 expression level, and also between the low levels of p53 and caspase 3 expression in the tumor cells are characteristic of intestinal-type gastric adenocarcinoma.

3 . The direct strong correlation between the medium proliferation index of the tumor cells and the low proliferation index of the stromal cells of intestinal-type gastric adenocarcinoma indicates a close association between the proliferative processes in the tumor cells and in the stromal cells of this carcinoma (the Spearman's coefficient for non-invasive carcinoma was 0.87 , and for invasive carcinoma it was 0.83 ).

4. The tumor cells of invasive intestinal-type gastric adenocarcinoma differs by the two times higher accumulation of p53 in comparison with the tumor cells of non-invasive 
intestinal-type gastric adenocarcinoma $(\mathrm{p}<0.05)$ [the medians of p53 expression level were $24.99 \%(6.56 ; 77.44)$ and $12.64 \%(11.40,15.40)$, respectively]. Besides, the tumor cells of non-invasive and invasive intestinal-type gastric adenocarcinoma are characterized by the low level of apoptosis, which is defined by the caspase 3 expression level [the medians of caspase 3 expression were 63.11 CUOD (45.94; $86.16)$ and 69.35 CUOD $(52.15 ; 95.42)$, respectively].

5 . The tumor cells of invasive intestinal-type gastric adenocarcinoma are characterized by the stronger association between the proliferation index and the accumulation of $\mathrm{p} 53$, compared with the tumor cells of non-invasive carcinoma [in the tumor cells of non-invasive carcinoma a direct weak correlation was revealed (the Spearman's coefficient $=0.31$ ) and in the tumor cells of invasive carcinoma a direct medium correlation was revealed (the Spearman's correlation coefficient $=0.49)$ ]

6 . The tumor cells of invasive intestinal-type gastric adenocarcinoma are characterized by the stronger association between the level of p53 accumulation and the caspase 3 expression level, compared with the tumor cells of non-invasive carcinoma [in the tumor cells of non-invasive carcinoma a direct weak correlation was revealed (the Spearman's coefficient $=0.35$ ) and in the tumor cells of invasive carcinoma a direct medium correlation (the Spearman's correlation coefficient $=0.56$ ) was revealed].

Conflicts of interest: authors have no conflict of interest to declare.

\section{References}

1. Torre, L. A., Bray, F., Siegel, R. L., Ferlay, J., Lortet-Tieulent, J., \& Jemal, A. (2015) Global Cancer Statistics, 2012. CA: A Cancer Journal for Clinicians, 65, 87-108. doi: 10.3322/ caac. 21262.

2. Fedorenko, Z. P., Hulak, L. O., Mykhailovych, Yu. Y., Horokh, Ye. L., Ryzhov, A. U., Sumkina, O. V., \& Kutsenko, L. B. (2015) Zakhvoriuvanist ta smertnist vid zloiakisnykh novoutvoren. Stan onkolohichnoi dopomohy naselenniu. Rak v Ukraini, 2013-2014: biuleten natsionalnoho kantser-reiestru Ukrainy, 16. [in Ukrainian].

3. Fedorenko, Z. P., Hulak, L. O., Mykhailovych, Yu. Y., Horokh, Ye. L., Ryzhov, A. U., Sumkina, O. V., \& Kutsenko, L. B. (2016). Zakhvoriuvanist ta smertnist vid zloiakisnykh novoutvoren. Stan onkolohichnoi dopomohy naselenniu. Rak v Ukraini, 2014-2015: biuleten natsionalnoho kantser-reiestru Ukrainy, 17. [in Ukrainian].

4. Kumar, V., Abbas, A., K., Fausto, N., Aster, D. K. (2014) Osnovy patologii zabolevaniy po Robbinsu i Kotranu [Robbins and Cotran Pathologic Basis of Disease]. Moscow: Logosphera [in Russian].

5. Tang, P., \& Tse, G. M. (2016) Immunohistochemical Surrogates for Molecular Classification of Breast Carcinoma: A 2015 Update. Archives of Pathology \& Laboratory Medicine, 140(8), 806-14. doi: 10.5858/arpa.2015-0133-RA.

6. Tumanskii, V. A., \& Zubko, M. D. (2015) E'kspressiya markerov progressirovaniya opukholi $\mathrm{v}$ gepato- $\mathrm{i}$ holangiocellyulyarnom rake pecheni raznoj velichiny [The expression of tumor progression markers in hepatocellular and cholangiocellular liver carcinomas of different sizes]. Current issues in pharmacy and medicine: science and practice, 2(18), 93-97. [in Ukrainian]. doi: http://dx.doi.org/10.14739/24092932.2015.2.46615

7. Tumanskiy, V. O., Baudarbekova, M. M., \& Chepets, O. V. (2014) Osoblyvosti protsesiv proliferatsii ta apoptozu v neinvazyvnii adenokartsynomi endometriiu ta adenokartsynomi $\mathrm{z}$ invaziieiu $\mathrm{v}$ miometrii [Specifi $\mathrm{c}$ features of proliferation and apoptosis in non-invasive adenocarcinoma of endometrium and adenocarcinoma with invasion into myometrium]. Pathologia, 1(30), 63-67. [in Ukrainian]. doi: http://dx.doi. org/10.14739/2310-1237.2014.1.25957.
8. Forones, N. M., Carvalho, A. S., Giannotti-Filho, O., Lourenço, L. G., \& Oshima, C. (2005) Cell proliferation and apoptosis in gastric cancer and intestinal metaplasia. Arquivos de Gastroenterologia, 42(1), 30-34. doi: 10.1590/S000428032005000100008.

9. Xiao, L. J., Zhao, S., Zhao, E. H., Zheng, X., Gou, W. F., Takano, Y., \& Zheng, H. C. (2013) Clinicopathological and prognostic significance of Ki-67, caspase-3 and p53 expression in gastric carcinomas. Oncology Letters, 6(5), 1277-84.

10. Dabbs, D. J. (2010) Diagnostic Immunohistochemistry. New York: Ch. Livingstone.

11. Amrani, H. J., Marchoudi, N., Sadaoui, I., Mahfoud, W., Elgnaoui, N., Haddad, F., et al. (2014) Ki-67 expression in gastric cancer and correlation with clinico-pathological characteristics. International Journal of Scientific and Research Publications, 4(6), 254-58.

12. Joo, Y. E., Chung, I. J., Park, Y. K., Koh, Y. S., Lee, J. H., Park, C. H., et al. (2006) Expression of Cyclooxygenase-2, p53 and Ki-67 in Gastric Cancer. Journal of Korean Medical Science, 21(5), 871-76. doi: 10.3346/jkms.2006.21.5.871.

13. Petrov, S. V., \& Rajkhlin, N. T. (2012) Rukovodstvo po immunogisokhimicheskoj diagnostike opukholej cheloveka [Guidance on immunohistochemical diagnosis of human tumors]. Kazan': Title [in Russian].

14. Uhlén, M., Fagerberg, L., Hallström, B. M., Lindskog, C., Oksvold, P., Mardinoglu, A., et al. (2015) The Human Protein Atlas. Retrived from http://www.proteinatlas.org.

15. Tumanskyi, V. O., Yevsieiev, A. V., Kovalenko, I. S., \& Zubko, M. D. (patentee) (2015) Patent 99314 Ukraina, MPK 2015.01 G01N 21/00 G06K 9/00 Sposib fototsyfrovoi morfometrii imunohistokhimichnykh preparativ [Patent of Ukraine 99314, IPC 2015.01 G01N 21/00 G06K 9/00 The technique of digital morphometry of immunohistochemical slides]. Biuleten, 10 [in Ukrainian].

16. Zheng, H., Tsuneyama, K., Cheng, C., Takahashi, H., Cui, Z., Murai, Y., et al. (2006) An Immunohistochemical Study of P53 and Ki-67 in Gastrointestinal Adenoma and Adenocarcinoma using Tissue Microarray. Anticancer Research, 3B(26), 2353-60.

17. Kania, J., Konturek, S. J., Marlicz, K., Hahn, E. G., \& Konturek, P. C. (2003) Expression of survivin and caspase-3 in gastric cancer. Digestive Diseases and Sciences, 48(2), 266-71.

\section{Information about authors:}

Tumanskiy V. A., MD, PhD, DSci, Professor, Head of the Department of Pathological Anatomy and Forensic Medicine, Zaporizhzhia State Medical University, Director of the Institute of Clinical Human Pathology, E-mail: tumanskiy@zsmu.zp.ua. Khrystenko T. A., Postgraduate Student, Department of Pathological Anatomy and Forensic Medicine, Zaporizhzhia State Medical University, E-mail: HristenkoTA@i.ua. 


\section{Відомості про авторів:}

Туманський В. О., д-р мед. наук, професор, зав. каф. патологічної анатомії та судової медицини, Запорізький державний медичний університет, директор Інституту клінічної патології людини, заслужений діяч науки та техніки України, E-mail: tumanskiy@zsmu.zp.ua.

Христенко Т. О., аспірант кафедри патологічної анатомії та судової медицини, Запорізький державний медичний університет, E-mail: HristenkoTA@i.ua.

Сведения об авторах:

Туманский В. А., д-р мед. наук, профессор, зав. каф. патологической анатомии и судебной медицины, Запорожский государственный медицинский университет, директор Института клинической патологии человека, заслуженный деятель науки и техники Украины, E-mail: tumanskiy@zsmu.zp.ua.

Христенко Т. А., аспирант каф. патологической анатомии и судебной медицины, Запорожский государственный медицинский университет, E-mail: HristenkoTA@i.ua. 